\title{
Early Childhood Behavior Management Strategy based on Fun Learning Environment
}

\author{
Akmal Mundiri ${ }^{\bowtie}$, Hasan Baharun1, Soniya ${ }^{2}$, Siti Hamimah² \\ Manajemen Pendidikan Islam, Universitas Nurul Jadid, Probolinggo, Indonesia( ${ }^{(1)}$ \\ Pendidikan Anak Usia Dini, Universitas Nurul Jadid, Paiton, Probolinggo, Indonesia( ${ }^{(2)}$ \\ DOI: $\underline{10.31004 / \text { obsesi.v6i4.2063 }}$
}

\begin{abstract}
The impact of the pandemic on student behavior can also be seen in face-to-face learning conducted after the pandemic. Face-to-face learning that was carried out after the pandemic made children feel like starting face-to-face learning that had been done before the pandemic. Thus, this study aims to reveal early childhood behavior management strategies based on a fun learning environment. This research uses a qualitative approach with the type of case study. This study resulted in the findings that early childhood behavior management strategies based on a fun learning environment were carried out by; 1) setting specific, observable, and measurable goals; 2) creating a structured environment with routines and schedules; 3) considering situational and environmental factors; 4) motivate with positive praise and attention, and; 5) cooperate with parents.
\end{abstract}

Keywords: behavior management; fun learning; environment; early childhood

\begin{abstract}
Abstrak
Pembelajaran di masa pandemi yang lebih sering dilakukan tanpa melibatkan interaksi antara guru dengan siswa, serta siswa dengan siswa sedikit banyak mengubah siswa. Dampak pandemi pada perilaku siswa juga tampak dalam pembelajaran tatap muka yang dilakukan setelah pandemic. Pembelajaran tatap muka yang dilakukan setelah pandemi membuat siswa seperti memulai kembali pembelajaran tatap muka yang telah dilakukan sebelum pandemic. Dengan demikian, penelitian difokuskan pada bagaimana pengelolaan perilaku anak usia dini yang berbasis pada lingkungan pembelajaran yang menyenangkanPenelitian ini menggunakan pendekatan kualitatif dengan jenis studi kasus. Penelitian ini menghasilkan temuan bahwa strategi pengelolaan perilaku anak usia dini yang berbasis pada lingkungan pembelajaran yang menyenangkan dilakukan dengan; 1 ) menetapkan tujuan yang spesifik, dapat diobservasi, dan terukur; 2) menciptakan lingkungan yang terstruktur dengan rutinitas dan jadwal; 3) mempertimbangkan factor situasi dan lingkungan; 4) memberikan motivasi dengan pujian dan perhatian yang positif, dan ; 5) bekerjasama dengan orang tua. Dengan demikian, pembelajaran selama dan setelah pandemic menciptakan ruang kreasi baru dalam hal manajemen tata kelola pembelajaran yang menyenangkan.
\end{abstract}

Kata Kunci: manajemen perilaku; pembelajaran yang menyenangkan; lingkungan; anak usia dini

Copyright (c) 2022 Akmal Mundiri, et al.

$\triangle$ Corresponding author:

Email Address : akmalmundiri@gmail.com (Paiton, Probolinggo, JawaTimur, Indonesia)

Received 14 September 2021, Accepted 23 December 2021, Published 24 January 2022 


\section{INTRODUCTION}

The pandemic makes educational institutions and teachers rack their brains so that the learning process can continue to be fun and not a double burden for children and parents (Suhairi \& Badrudin, 2021; Rahman \& Subiyantoro, 2021). There are times when children fill their spare time by watching television, listening to the radio, playing the play station not because they are interested in these activities, but because there is nothing they can do other than that. Therefore, as parents, we must choose wisely and develop positive interests for children. These conditions make educational institutions immediately carry out a transformation of learning governance while still prioritizing the main objectives of learning that lead to changes in student behavior. These modifications impact the patterns, models, strategies, and methods that teachers employ. Teachers must be flexible to manage change and make learning enjoyable in this environment.

Therefore, to support success in learning in the classroom, teacher competence and the personal attributes of teachers need to be considered before teaching. In addition to this, several factors influence success in teaching in the classroom. The success of teachers in managing to learn is influenced by several factors, which include; 1) Personal character/interest, 2) Educational experience and pedagogic knowledge, 3) school context. Learning experiences need to be formed in a person because through experience, and new knowledge can be formed for someone. Learning is a change in behavior caused by experience (Alves et al., 2017). As defined by Slameto (2010), learning is an effort process carried out by a person in order to obtain a new behavior change as a whole, as a result of his or her own experience in interacting with his or her surroundings. Akinde, Harr, \& Burger (2017) say that through field experience programs, teachers will gain deep insight into leadership and classroom teaching and improve educational leaders' skills.

Teachers must have a firm grasp of effectively managing student behavior in the classroom. As a class leader, the teacher has the authority to influence how children learn, what they know, and the development of students' character characteristics (Rasmani et al., 2021). The ability to effectively manage student behavior in the classroom will impact the optimization of the learning process. This is consistent with the findings of research conducted by Ratcliff et al., who discovered that teachers' quality and quantity of behavior management has a significant impact on the teaching-learning environment (Ratcliff et al., 2014). When the teacher can create an environment conducive to learning, the learning process will be maximized (Umiarso \& Hidayati, 2022). As a result, prospective teachers must be well-versed in effective classroom management. In contrast, according to the findings of various studies, someone with a background in teacher education does not necessarily automatically become adept at effective classroom management practices. It must be backed up by a sufficient amount of experience (Helsa \& Hendriati, 2017).

Thus, in carrying out their duties, teachers must also have competencies that are prerequisites in carrying out their roles as teachers. According to Mulyasa, as quoted by Jejen Mustofa said that teacher competence is a collaboration between personal, scientific, technological, social, and spiritual abilities, which kaffah forms the fundamental professional competence of teachers, including mastery of the subject matter, understanding of children, educational learning, and improved personal development. Kaffah develops the basic professional competence of teachers. excellent, as well as professionalism (Munawar, 2019; Onia \& Elkhder, 2021). One of the competencies that a teacher must master is a good personality competency as reflecting an adult, wise, authoritative attitude, being a role model, and having noble character (Wahyudin et al., 2021).

The teacher is an essential factor that can determine the quality of education because the teacher deals directly with children in the learning process in the classroom (Aryani et al., 2021; Wahyudin et al., 2021). In the hands of teachers, the personality qualities of children are formed. Therefore, a competent, responsible, and skilled teacher is needed. No matter how good the existing curriculum and education system is, everything will be in vain without being 
supported by teacher competence (Fardiah et al., 2019). Teachers are competent and responsible, especially in overseeing the development of children to a maximum point. The real spirit of education lies on the shoulders of the teachers. The good or bad of education is in the hands of the teacher. This is because the teacher has a strategic role in carving children into intelligent, skilled, moral, and knowledgeable people (Mundiri \& Bariroh, 2019).

The description above confirms that the teacher has an essential role in the learning system. The teacher is responsible for the policy line inherent in the teacher because the teacher has a variety of names according to the study of Islamic education thought. The teachers' names include ustadz, mu'allim, murabbiy, mursyid, mudarris, and muaddib, which means people who provide knowledge to educate and foster the morals of children to become people with good personalities (Dakir, 2018; Bali et al., 2020).

Similarly, the position of the teacher in the learning process in early childhood. In the last few decades, learning problems in early childhood tend to be directed at academic abilities only (Iltiqoiyah, 2020). In this case, learning emphasizes achieving children's ability to read, write and count (calistung). The learning carried out in early childhood is not solely for calistung abilities. However, it is more directed to develop children's various potentials, such as physical, cognitive, language, and socio-emotional (Tatminingsih, 2019; Nisa, 2020).

This tendency is caused by a misunderstanding of early learning in early childhood (Fika et al., 2019). Learning at the age of the world should be more directed to the development of potential based on the stages of development. Each age stage that a child goes through will show different characteristics from the stages he has passed and will pass. If the treatment is not based on the child's development, it will only place the child in a suffering condition. Learning based on development will improve the skills and interests of children. Conducive learning conditions for early childhood can only be achieved if social interaction occurs well. Good social interaction allows each person to create a pattern of relationships without anything that interferes with their relationship (Mundiri \& Adhimiy, 2019). A conducive classroom atmosphere can prevent boredom, boredom, and psychological fatigue. On the other hand, a conducive classroom will foster interest, motivation, and learning endurance. The learning atmosphere can be fun for children if the teacher presents and uses humor appropriately. Therefore, to help teachers create learning conditions and an atmosphere of interaction that can invite and challenge children to be actively creative, conducive, and fun learning means that children and children can readily accept the material presented by the teacher will be more interested in exploring the material presented by the teacher (Fardiah et al., 2019; Fardiah et al., 2019). Religion also recommends that in the delivery of knowledge, a teacher must be in a way that is full of tenderness. Based on the description above, this research will focus on behavior management strategies based on a fun learning environment.

\section{METHODOLOGY}

This research uses a qualitative approach with the type of case study. Thus, this study reveals behavior management strategies based on a pleasant learning environment at RA Ranugedang Tiris Probolinggo. This study focuses intensively on cases that occurred in RA Ranugedang Tiris Probolinggo. Thus, this research was carried out holistically and significantly in a particular case of a pleasant learning environment-based behavior management strategy teachers at RA Ranugedang Tiris Probolinggo. The main instrument in this study is the researcher, who works as a critical instrument. This study's sources of data are informants who know and are involved in management based on a pleasant learning environment at RA Ranugedang Tiris Probolinggo, which consists of teachers, principals, children, parents, and the community around the location.

For researchers to obtain data on behavioral management strategies based on a fun learning environment, the use of participant observation techniques, in-depth interviews, documentation, and focus group discussions as techniques in collecting data. Data collection is carried out until there is data saturation. After the data was collected, the researchers 
analyzed the Miles and Huberman data analysis technique, which consisted of data reduction, data display, and leverage. In order to obtain credible data, the researchers used additional participation, technical observation, and training. The process of checking the validity of the data through triangulation techniques is carried out by technical triangulation methods, source triangulation, and theoretical triangulation.

\section{RESULTS AND DISCUSSION}

This research focused on early childhood behavior management strategies based on a fun learning environment at RA Ranugedang Tiris Probolinggo produced the following findings;

\section{Setting Specific, Observable, and Measurable Goals}

Teachers carry out behavior management strategies based on a pleasant learning environment based on research results by setting specific, observable, and measurable behavior formation goals. Thus, teachers at RA Ranugedang Tiris Probolinggo formulate the goals of the desired behavior. These goals are explicitly formulated, can be observed, and are measurable. Thus, teachers can identify behaviors that fall into good behavior and bad behavior. Goal setting can also work as a motivational process because goal setting can create a discrepancy between current performance and expected performance (Mundiri \& Sa'adah, 2018). Based on the goals that have been set, the teacher can see gaps or descriptions between them. In this case, It is much easier for kids to follow the rules when they understand precisely what good behavior entails. Uncertainty and anxiety might result from unclear expectations; after all, youngsters will feel it is unfair to be punished for breaking an ambiguous law. At the same time, do not overwhelm the children with so many rules that they forget them all. Strike a balance between generality and specificity that is age-appropriate, and assist children by providing tangible examples and visual aids.

The success of the behavior management strategy by setting specific, observable, and measurable goals based on research can be influenced by the teacher's commitment to carrying out what has been planned. In this case, commitment is an agreement or agreement between employees and the company. Gibson et al. stated that commitment is a condition that involves identification and embodied loyalty to the company where the individual works (Baharun, 2016).

According to Gibson, goal setting is the process of setting goals or objectives in work. This goal-setting process involves superiors and subordinates jointly determining or setting goals or work goals that their workforce will carry out as task bearers within a certain period. Meanwhile, according to Davis, goal setting is the management of setting goals or objectives to achieve performance. Then Cascio stated that goal setting is based on directing behavior towards a goal, and goals or targets can be added by explaining to the workforce how to do the task and why the goal or goal is essential to implement.(Pratiningsih \& Sahrah, 2016) Thus, the description as above confirms that goal setting is a guide or reference that will direct individuals to act and work that describes the ideal state to be achieved in the future or shows a plan to achieve the desired results. The planning process in setting goals carried out by teachers at RA Ranugedang Tiris Probolinggo is carried out by identifying targets, setting priorities, considering time, reviewing progress, and determining behavioral indicators. Goal setting provides positive input for student achievement, as shown in the figure 1. 


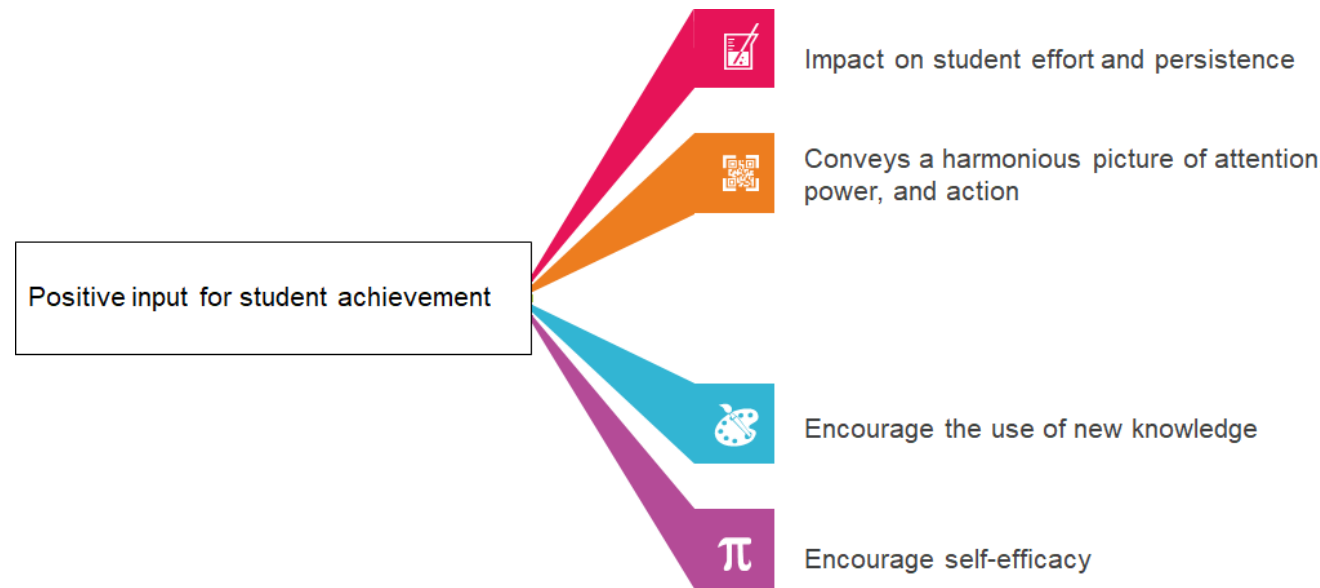

Figure 1. Relationship between goals and achievements

The picture as above explains that there are four mechanisms of the relationship between goals and achievements, namely; high goals lead to high effort and perseverance; goals give direction to attention, power, and action to achieve the appropriate goals; the goal of encouraging employees to use the new knowledge; and goals related to self-efficacy, namely personality traits, input, participation in decision making, job autonomy and incentives.

\section{Creating a Structured Environment with Routines and Schedules}

The teacher's strategy in managing student behavior at RA Ranugedang Tiris Probolinggo is done by creating a structured, routine, and scheduled environment. Routines and schedules provide children with a sense of safety in their surroundings, which leads to confidence, contentment, and good behavior. Uncertainty about what will happen or what to do can lead to worry, which can lead to undesirable conduct, or it might allow children to become distracted and disturb the situation. Sedangkan A daily visual calendar helps children remember what they need to do next so that they don't lose focus throughout transitions. Routines also assist in guiding children through their daily activities in a fun and memorable manner, motivating them to accomplish what is required of them, whether it is eating lunch or putting away toys (Page \& Jones, 2018).

The process carried out by creating a structured and scheduled environment is part of the habituation that is the primary bearer in the formation of character in children. Habituation is one method that is the primary method in character building. Habituation in religious education should start as early as possible. Rasulullah SAW ordered parents, in this case, educators, that they tell their children to pray when they are seven years old. Education often takes the instant way so that it automatically eliminates habituation. Tradition and character can be formed through practice and habituation. When a practice is used to being done, thanks to habituation, it will become a habit for those who do it, then it will become addicted, and in time it becomes a tradition that is difficult to leave (Wiyani \& Purwokerto, 2020).

In implementing this habituation, an integrative approach is needed between schools, communities, and parents in the family environment. Schecter, in his study, provides an understanding that teachers' disposition to involve parents in schools provides benefits related to curriculum orientation for parents, opening lines of communication, building communities, diversifying sources, advocating for parents. Likewise, Oladipo stated that "moral education was responsible for all. Because each child from birth belongs to a significant group, so family members, friends, relatives, teachers and administrators play a major role in the formation of the character of each child"(Oladipo, 2009). Thus, there is an educational process with an integrative approach between schools, communities, and parents, as shown in the following figure: 


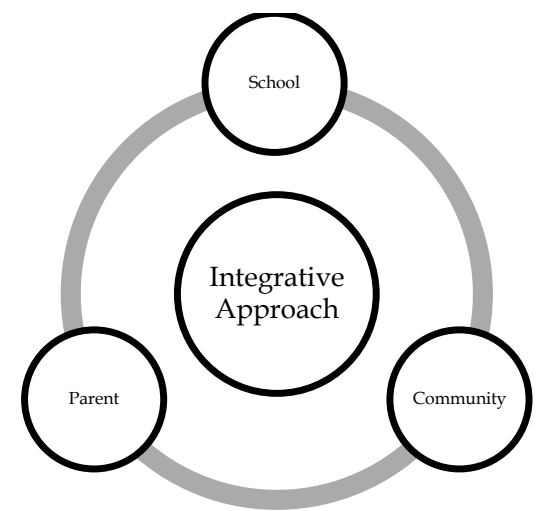

Figure 2. Integrative approach in habituation

Thus, the support and cooperation between the three educational institutions facilitate the process of internalization and alignment of educational goals. The similarity of views, stimulus and treatment will make student behavior easier to direct. The psychology of behaviorism states that habits can be formed because of conditioning or giving a stimulus. The stimulus given must be repeated so that the desired reaction (response) appears. Based on Pavlov's experimental results, namely classical conditioning or classical habituation. Pavlov chose the dog for the experiment. Before giving the condition, the dog did not salivate when the bell was rung, but after the bell was rung and accompanied by food in the form of meat, the dog salivated. This activity was carried out continuously and repeatedly. This causes the dog to salivate when the bell is rung. Once when the bell was rung without food, the dog kept salivating. From the experiment, it can be concluded that a behavior that is initially very difficult to do, but because it is often repeated, eventually will get used to mastering and carrying out the behavior. So the strategy to instill and implement character education can be done through habituation in children. Children not only learn right from wrong through habituation, but they also feel and can distinguish between good and wrong values, and they will be willing to do it or not. Once a behavior has been established through habituation, changing or eliminating it will be difficult (Suyono \& Hariyanto, 2014).

Therefore, as a beginning in the educational process, habituation is a very effective way of instilling moral values into the soul of a child. The values embedded in him will then manifest in the child's life since he begins to step into adolescence and adulthood (Armai, 2002). Habituation is one of the essential educational methods, especially for children. They have not realized excellent and evil in the moral sense. They also do not have the obligations that must be done as adults. So they must become familiar with various behaviors, skills, abilities, and mindsets before they can function effectively. Children must become accustomed to something positive. Then they will turn all of the positive characteristics into habits, allowing the soul to carry out the pattern without exerting excessive effort, without expelling excessive energy, and without encountering numerous difficulties (Nata, 2005).

A child who has been accustomed to specific activities and practices will carry them out quickly and happily. Everything formed as a habit at a young age is difficult to break and continues into old age. Treatment and self-control are frequently required to bring about lasting change. On this basis, education experts always remind children to immediately familiarize themselves with something that is expected to become a good habit before having other habits contrary to it. Practical action has an important position in Islam. With all the explanations, Islam requires humans to direct their behavior, instincts, and even their lives to realize the divine laws practically. (Mundiri \& Sa'adah, 2018). This practice will be challenging to carry out if someone is not trained and accustomed to carrying it out.

Forming new habits or improving existing practices is referred to as habit learning. In addition to using orders, role models, and one-of-a-kind experiences, learning habits use punishments and rewards to reinforce their behavior. This is accomplished by assisting the 
child in developing new attitudes and practices of action that are more appropriate and positive because they are in harmony with the requirements of space and time (contextual). Furthermore, the correct and positive meaning provided above is consistent with the prevalent moral norms and values, including religious, traditional, and cultural values.

\section{Considering Situational and Environmental Factors}

In a fun learning process, the teacher of RA Ranugedang Tiris Probolinggo prioritizes situational and environmental factors in determining the planning of core activities in the learning process. In the learning process in this activity, the teacher pays attention to the condition of the childs and the situation around the childs. Thus, the teacher of RA Ranugedang Tiris Probolinggo did not rigidly apply the planning that had been done as stated in the learning tool. Consideration of the situation and condition of childs is one way to keep learning fun without denying the purpose of learning.

Childs experience a learning process that generally has mandatory and basic needs that must be met and cannot be avoided. These needs vary, ranging from eating and drinking and those related to personality, such as security, love, self-esteem, success, and so on. Maslow believed that humans are moved to understand and accept themselves as much as possible. His famous theory is the hierarchy of needs. Furthermore, according to him, humans are motivated to fulfill their life needs. These needs include physiological needs, safety, and security; the need to be loved and cherished; the need will be appreciated, and selfactualization needs (Iskandar, 2009).

Several studies have shown that security is an essential need for children and significantly affects their behavior. Rutter et al., as revealed by Desmita, noted that behavioral and academic achievements tend to be good when school conditions are clean and have good decorations. Murphy also claims that an effective school is determined by a safe and orderly environment for learning (Desmita, 2016).

Achievement of maximum learning achievement is the goal of every learning activity, but there are still children who lack achievement. Each learning environment has a different influence on student achievement. In improving student achievement, not all learning environments have a positive effect. Collaboration between children is still lacking so that it hampers the smooth teaching and learning process. Not all children are ready to accept the lessons delivered in teaching and learning activities. The difference in the level of student learning readiness affects learning achievement. The learning environment (by experts, it is often referred to as the educational environment) is a place where learning activities take place that influences the sustainability of these activities. The educational environment includes 1) family environment and 2) school environment. In the context of family development, the family environment encompasses all conditions and external influences on the lives and development of family members, including how parents educate their children, the relationships between family members, the home atmosphere, the economic conditions of the family, the understanding of parents, and cultural background (Mundiri \& Adhimiy, 2019). Students are familiarized with school discipline and the values of learning activities in various fields of study, such as teaching methods, curriculum, teacher-student relationships, school discipline, learning tools, and school time. Students are also familiarized with a higher standard of study than is required by their school's size or the condition of the building, as well as the importance of homework.

During the learning process, children will have interactions with their surroundings. The environment stimulates the individual, and the individual promotes the environment. Individual responds to their surroundings. Individual behavior can change due to the interactional process between two people. Favorable or unfavorable changes in behavior can occur due to the events. Children require a comfortable, quiet environment that is free of distractions and conducive to learning during the learning process; this environment must be free of noise. To concentrate well and easily absorb lessons, students require a conducive 
environment to perform. A less conducive environment will interfere with the learning process, causing difficulty retaining information from their studies. The learning environment is a space where all of its contents are interconnected with learning activities. It comprises the following: To increase the comfort of the individuals who occupy the learning environment to carry out learning activities, the learning environment must be designed to support learning activities. The learning environment impacts the processes and outcomes of student behavior, either directly or indirectly, depending on how it is intended. Providing a safe and stimulating learning environment for children should be given first consideration. This is a critical success factor in developing children's behavioral abilities. (Rosfiani et al., 2019).

The school environment included in the social environment is all school members, be it teachers, employees, or classmates, all of which can affect the spirit of learning a student. Teachers who can show good attitudes and behavior and show good examples, especially in terms of studying, such as diligently reading, can provide positive motivation for student learning. Likewise, if children' classmates at school have good attitudes and behavior and a good work ethic, for example, studying hard will positively affect student learning.

\section{Motivating with Praise and Positive Attention}

In order to create fun learning, teacher RA Ranugedang Tiris Probolinggo also provides the motivation that is done with praise and positive attention. Children in their early years need to understand that doing their best will be rewarded. Positive feedback demonstrates that good behavior helps them as well, so they are motivated to be a good community member. Furthermore, it assists them in learning what good behavior looks like in practice by offering instances (both in themselves and in other children) that they can use to create a mental model of good behavior. Teachers carry out the process of giving praise in the context of motivation at RA Ranugedang Tiris Probolinggo by making eye contact with children, giving praise with a smile, explaining the reasons for the praise given to motivate similar actions, either by the concerned student or other children and making notes of success. so that the teacher can make connections in the task or material to be delivered.

Learning motivation is essential for a teacher to know. Knowledge and understanding of student learning motivation are helpful for teachers. The benefits are as follows; 1) Generating, improving, and maintaining children' enthusiasm to learn until they succeed; arousing if children are not excited; improving when the spirit of learning arises and sinks; maintaining if the spirit has been vital to achieving learning goals. In this case, gifts, praise, encouragement, or encouragement can be used to ignite enthusiasm for learning; 2) Knowing and understanding children' learning motivation in various classes; some are indifferent, some are not paying attention, some are playing, in addition to those who are eager to learn. With various learning motivations, the teacher can use various teaching-learning strategies; 3) Increase and make teachers aware of choosing one of the various roles such as advisor, facilitator, instructor, discussion partner, motivator, gift giver, or educator. The pedagogical role is, of course, following student behavior, and; 4) Provide opportunities for teachers to "performance" pedagogical engineering. The teacher's job is to make all children learn until they succeed. The professional challenge lies in "transforming" disinterested children into a passion for learning. Learning motivation is the need to develop self-ability optimally to do better, achieve, and be creative. Learning motivation is an internal and external drive that causes a person (individual) to act or act to achieve goals so that children' behavior changes are expected to happen (Nashar, 2004). The efforts made by the teacher by giving praise and attention are motivation with objective motives. Objective motives arise because of the urge to deal with the outside world effectively, for example, the urge to explore and the urge to take an interest.

Thus, motivation has a strategic role in one's learning activities. No one learns without motivation. No motivation means no learning activities. There are several principles of motivation in learning, namely: motivation as the fundamental driving force that drives 
learning activities, intrinsic motivation is more important than extrinsic motivation in learning, motivation in the form of praise is better than punishment, motivation is closely related to learning needs, motivation can foster optimism in learning. learning, and motivation gives birth to learning achievement (Djamarah, 2011). An essential principle is a motivation as the driving force for encouraging learning activities. A person performs a learning activity because someone is pushing it.

Furthermore, intrinsic motivation is more important than extrinsic motivation in learning. Learners who learn based on intrinsic motivation are very little influence from the outside. His enthusiasm for learning is robust. Children learn not to influence by getting high scores, expecting praise, and expecting prizes because they gain as much knowledge as possible. So intrinsic motivation is more important in learning.

The motivation in the praise given by the teacher RA Ranugedang Tiris Probolinggo is better than punishment. Everyone likes to be appreciated and does not like to be punished. Praising others means giving appreciation. This encourages the improvement of performance further. Unlike praise, punishment is given to children to stop their negative behavior. The following principle is that motivation is closely related to learning. The need that children cannot avoid is their desire to master several sciences. So children need reasonable needs in learning. In addition, motivation can foster optimism in learning. Children are confident that they can complete any work they do. High and low motivation is always used to indicate good or bad student achievement or high and low student learning outcomes.

Efforts that have been made to provide motivation, whether done by giving praise or attention, or even in other ways, are a psychic driving force in children that can lead to learning activities and ensure continuity of learning to achieve learning goals. Therefore, motivation plays an essential role in providing passion, enthusiasm, and pleasure in learning. Children who have high motivation have much energy to carry out learning activities (Djamarah, 2011). Stimulation and affection will also affect a person's motivation to learn. Stimulus is a change in perception or experience with the environment that makes a person active. Stimuli can make a person active and motivated to do an activity. For example, stimulating engaging learning media can lead to student learning motivation. Affection is an emotional experience of anxiety, concern, and ownership of an individual or group at the time of learning. A person's emotions are related to the impulses in him. Therefore, affection can affect learning motivation.

Likewise, the strengthening factor can increase student motivation. Reinforcement is an event that maintains or increases the likelihood of a response. Reinforcement can be in the form of high test scores, praise, social rewards, and attention. Reinforcement can be in the form of positive reinforcement and negative reinforcement. Positive reinforcement can improve behavior. Negative reinforcement is an aversive stimulus (a feeling of disapproval accompanied by an urge to refrain) or an event that must be replaced or reduced in intensity. The teacher's attention includes positive reinforcement that can improve behavior or learning motivation.

\section{Collaborating with Parents}

Collaborating with parents in managing early childhood behavior is one way to create a fun learning environment. The collaboration with parents was carried out by the teacher RA Ranugedang Tiris Probolinggo by giving and asking children' parents to fill out a liaison book between the school and the family. In the link book, parents are asked to fill out activity sheets and student behavior in their respective homes. However, it also asks parents to provide behavioral input for negative behavior towards children. According to Boyd, parents and family, teachers and peers play a crucial role in achieving good emotional development in children according to their age stages. Parents must interact to show affection, understand the child's feelings, understand the child's wants and needs, express the child's interest in daily activities, be proud of the child's achievement, provide support and enthusiasm for the child 
in dealing with various things. Teachers, like parents, must show a warm and responsive relationship, a consistent attachment while the child is in school (Mashar, 2015).

A collaborative relationship between schools and families, or between teachers and parents, in the learning process carried out by their children, is defined as one in which both parties are aware of each other's identities and goals and their mutual understanding, respect, and support. Collaboration is essential to the achievement of educational purposes in the learning process. for the benefit of children. This collaboration has the potential to inform or reach out to parents, educating them on their responsibilities and roles in their children's educational process at school. Parenting programs, in conjunction with teachers, can aid in developing children's intelligence (Fadjukoff et al., 2016). Developing parental skills in fostering children's emotions can be done through parenting programs. As for other collaborations that can be done by parents and teachers, namely through the inaugural meeting of parents before school activities start, the school explains what activities are carried out at school. Meetings with parents discussed developing children's emotions, communicating with parents through WhatsApp groups, and sending videos of activities carried out by children to parents. Parents' involvement in their children's learning at home, as well as their ability to make decisions about their children's education.

Nowadays, collaboration with various parties is required to carry out various educational activities. Among the many activities involved in achieving educational objectives are collaborations between both internal and external parties to the institution pursuing the goal of education. Collaboration with the school itself, universities, communities, and experts can positively impact student achievement and school experience and can be accomplished in a variety of ways. As a result, collaboration is a tangible and systematic step in the educational environment that directly impacts the overall quality of education (Windayanti et al., 2017). To create an environmental atmosphere that provides opportunities for children is carry out creative activities effectively with children while studying, intensive communication is needed with parents and the community as partners for the school. Parents and teachers can be contributors to the growth and development of children. Parents can be better acquainted with the programs carried out at school, and teachers are more concerned with the situation of children at home. As they learn about goals, they can support each other and work together with their children. Thus, teachers must strengthen relationships with parents as part of an effort to create a fun learning space for children.

The same is valid for learning conducted in online mode. Learning activities in online mode are also positively and significantly related to parents' level of education. The level of education provides insight and understanding of the benefits and harms of internet media for children. Adequate levels of education tend to understand and use information technology well. Therefore, the higher the education level of mothers, the more they care about their children using the internet for education. Meanwhile, in general, guiding children is entrusted to mothers. Fathers are more focused on work. In addition to the role of parents in children' online learning, the role of teachers towards children in using the internet for learning activities is crucial. The intensity of the teacher giving lesson assignments to utilize the internet is positively and significantly related. Thus, the collaboration of parents and teachers in online learning is also part of the effort to create a fun learning space while considering the level of development and learning objectives.

\section{CONCLUSION}

Based on the discussion above, research on early childhood behavior management strategies based on a fun learning environment at RA Ranugedang Tiris Probolinggo was carried out by; setting specific, observable, and measurable goals; creating a structured environment with routines and schedules; considering situational and environmental factors; motivating with praise and positive attention; cooperate with parents. The collaborative parenting pattern between parents and teachers is one of the early childhood behavior 
management strategies that can bridge information for both parties, both teachers and parents. This information becomes an essential input in managing behavior as desired in the learning process.

\section{AKNOWLEDGEMENT}

The researcher would like to thank the Chancellor of the University of Nurul Jadid, Paiton, Probolinggo, East Java, who has supported researchers to complete this research. Next, the researcher would like to thank the principal and teacher of RA Ranugedang Tiris Probolinggo. The researcher also thanks to the Obsession Journal's editorial team for providing the opportunity for researchers to publish the results of this study.

\section{REFERENCES}

Akinde, O. A., Harr, D., \& Burger, P. (2017). Field Experience: Experiential Learning as Complementary to the Conceptual Learning for International Students in a Graduate Teacher Education Program. International Journal of Higher Education, 6(4), 137. https://doi.org/10.5430/ijhe.v6n4p137

Alves, P., Miranda, L., \& Morais, C. (2017). The Influence of Virtual Learning Environments in Students' Performance. Universal Journal of Educational Research, 5(3), 517-527. https:// doi.org/10.13189/ujer.2017.050325

Armai, A. (2002). Pengantar Ilmu dan Metodologi Pendidikan Islam. Ciputat Press.

Aryani, E., Hasanah, A. U., \& Putra, H. D. (2021). Effect of Head Management Competence on Teacher Performance in SMA Nusantara Plus. Al-Tanzim: Jurnal Manajemen Pendidikan Islam, 5(2), 105-114. https:// doi.org/10.33650/al-tanzim.v5i2.2177

Baharun, H. (2016). Management of Quality Education in Pesantren: The study of The Education Quality Improvement Pesantren by Strategy Management Approach. 2nd International Conferences on Education and Training (ICET), 695-702.

Bali, M. M. E. I., Muali, C., \& Munawaroh, L. (2020). Self-Efficacy sebagai Media Peningkatan Profesionalisme Guru di Madrasah. Risalah: Jurnal Pendidikan Dan Studi Islam, 6(1), 244-257. https://doi.org/10.31943/jurnal_risalah.v6i2.158

Dakir. (2018). Pengaruh Gaya Kepemimpinan Situasional Kepala Sekolah dalam Supervisi Akademik terhadap Kompetensi Profesional dan Kinerja Guru. K-Media.

Desmita, D. (2016). Psikologi Perkembangan Peserta DIdik: Panduan bagi orangtua dan guru dalam memahami psikologi anak usia, SD, SMP dan SMA. Remaja Rosdakarya.

Djamarah, S. B. (2011). Psikologi Belajar. Rineka Cipta.

Fadjukoff, P., Pulkkinen, L., Lyyra, A.-L., \& Kokko, K. (2016). Parental Identity and Its Relation to Parenting and Psychological Functioning in Middle Age. Parenting, 16(2), 87-107. https://doi.org/10.1080/15295192.2016.1134989

Fardiah, F., Murwani, S., \& Dhieni, N. (2019). Meningkatkan Kemampuan Kognitif Anak Usia Dini melalui Pembelajaran Sains. Jurnal Obsesi: Jurnal Pendidikan Anak Usia Dini, 4(1), 133. https://doi.org/10.31004/obsesi.v4i1.254

Fika, Y., Meilanie, S. M., \& Fridani, L. (2019). Peningkatan Kemampuan Bicara Anak melalui Bermain Peran Berbasis Budaya. Jurnal Obsesi : Jurnal Pendidikan Anak Usia Dini, 4(1), 50. https://doi.org/10.31004/obsesi.v4i1.229

Helsa, H., \& Hendriati, A. (2017). Kemampuan Manajemen Kelas Guru: Penelitian Tindakan di Sekolah Dasar dengan SES Rendah. Jurnal Psikologi, 16(2), 89. https://doi.org/10.14710/jp.16.2.89-104 
Iltiqoiyah, L. (2020). Manajemen Pembelajaran melalui Pendekatan BCCT dalam Meningkatkan Multiple intelligences Anak. Jurnal Obsesi : Jurnal Pendidikan Anak Usia Dini, 5(2), 1368-1381. https:// doi.org/10.31004/obsesi.v5i2.781

Iskandar, I. (2009). Psikologi Pendidikan (Sebuah Orientasi Baru). Gaung Persada Press.

Khairun Nisa, S. (2020). Efektivitas Komunikasi Guru terhadap Motivasi Belajar Anak Usia Dini. Jurnal Pendidikan Anak Usia Dini, 5(1), 229-240. https://doi.org/10.31004/obsesi.v5i1.534

Mashar, M. (2015). Emosi Anak Usia Dini dan Strategi Pengembangannya. Prenada Media.

Munawar, M. (2019). Supervisi Akademik: Mengurai Problematika Profesionalisme Guru di Sekolah. Al-Tanzim: Jurnal Manajemen Pendidikan Islam, 3(1), 135-155. https:// doi.org/10.33650/al-tanzim.v3i1.522

Mundiri, A., \& Adhimiy, S. (2019). Religious Authoritative Parenting Berbasis Quantum Meaningfullness of Life; Melejitkan Potensi Raih Prestasi. Pustakan Nurja.

Mundiri, A., \& Bariroh, A. (2019). Amplifikasi Profesi Guru Dalam Proses Pendidikan Transformatif Perspektif Al-Ghazali. Jurnal Ilmiah Islam Futura, 18(1), 159-184. https://doi.org/10.22373/jiif.v18i1.3288

Mundiri, A., \& Sa'adah, R. (2018). Purifikasi Tujuan Pendidikan Perspektif Ibn "Ațā"illāh. Dirāsāt: Jurnal Manajemen dan Pendidikan Islam, 4(2), 172-193.

Nashar, N. (2004). Peranan Motivasi dan Kemampuan awal dalam kegiatan Pembelajaran. Delia Press.

Nata, A. (2005). Filsafat Pendidikan Islam. Logos Wacana.

Oladipo, S. . (2009). Moral Education of the Child: Whose Responsibility? Journal Sec Sei, 20(2), 149-156. https:// doi.org/10.1080/09718923.2009.11892733

Onia, S. I., \& Elkhder, E. (2021). the Effect of Principals'Management Styles on Teachers'Performance in Private Primary Schools in Omdurman Locality in Sudan. Managere: Indonesian Journal of Educational, 3(1), 62-74. https://doi.org/10.52627/ijeam.v3i1.89

Page, A., \& Jones, M. (2018). Rethinking Teacher Education for Classroom Behaviour Management: Investigation of an Alternative Model using an Online Professional Experience in an Australian University. Australian Journal of Teacher Education, 43(11), 84-104. https://doi.org/10.14221/ajte.2018v43n11.5

Pratiningsih, P., \& Sahrah, A. (2016). Pengaruh Pelatihan Goal Setting Terhadap Efikasi Diri Manajer Tingkat Menegah Di Pt Bat Yogyakarta. Insight: Jurnal Ilmiah Psikologi, 18(2), 191. https://doi.org/10.26486/psikologi.v18i2.396

Rahman, A., \& Subiyantoro, S. (2021). The Leardership Role of School Principals in Online Learning During the Covid-19 Pandemic. Al-Tanzim: Jurnal Manajemen Pendidikan Islam, 5(1), 165-175. https:// doi.org/10.33650/al-tanzim.v5i1.1805

Rasmani, U. E. E., Rahmawati, A., Palupi, W., Jumiatmoko, J., Zuhro, N. S., \& Fitrianingtyas, A. (2021). Manajemen Soft skills Guru dalam Menguatkan Mutu Pembelajaran di PAUD. Jurnal Obsesi: Jurnal Pendidikan Anak Usia Dini, 6(2), 886-893. https://doi.org/10.31004/obsesi.v6i2.1584

Ratcliff, N. J., Carroll, K. L., \& Hunt, G. H. (2014). Teacher retreating: the little known behavior that impacts teaching and learning. Education, 135(2), 169-181.

Rosfiani, O., Akbar, M., \& Neolaka, A. (2019). Assessing Student Social Studies Learning: Effects of Learning Environment, Inquiry, and Student Learning Interest. TARBIYA: 
Early Childhood Behavior Management Strategy based on Fun Learning Environment

DOI: 10.31004/obsesi.v6i4.2063

$\begin{array}{llll}\text { Journal of Education in Muslim } & \text { 46-57. }\end{array}$ https://doi.org/10.15408/tjems.v6i1.11593

Slameto. (2010). Belajar dan Faktor-Faktor Yang Mempengaruhinya. Rineka Cipta.

Suhairi, \& Badrudin. (2021). Implementation of Academic Supervision of Islamic Religious Education During The Covid-19 Pandemic. Curriculum Management In Improving Competitive Advantage in $20-30$. https://doi.org/10.52627/ijeam.v3i2.129

Sukmadinata, N. S. (2009). Landasan Psikologi Proses Pendidikan. Rosdakarya.

Suyono, S., \& Hariyanto, H. (2014). Belajar dan Pembelajaran Teori dan Konsep Dasar. Remaja Rosdakarya.

Tatminingsih, S. (2019). Alternatif Stimulasi Kemampuan Kognitif melalui Penerapan Model Pembelajaran Berbasis Permainan Komprehensif. Jurnal Obsesi : Jurnal Pendidikan Anak Usia Dini, 3(1), 183. https:// doi.org/10.31004/obsesi.v3i1.130

Umiarso, \& Hidayati, N. (2022). Improving Children â€TM s Cognitive Intelligence Through Literacy Management. Jurnal Obsesi: Jurnal Pendidikan Anak Usia Dini, 6(3), 15881598. https:// doi.org/10.31004/obsesi.v6i3.1817

Wahyudin, U. R., Winara, D., \& Permana, H. (2021). Teacher Professionalism Improvement Management: Study of Principal Leadership at SMA Al-Ittihad Karang Tengah Cianjur. Al-Tanzim: Jurnal Manajemen Pendidikan Islam, 5(2), 115-124. https://doi.org/10.33650/al-tanzim.v5i2.2222

Windayanti, K., Suarnajaya, I. W., \& Agustini, D. A. E. (2017). An Analysis Of Communication Strategies Used By Teacher In English Teaching And Learning At Sma Saraswati Singaraja. Jurnal Pendidikan Bahasa Inggris, 5(2).

Wiyani, N. A., \& Purwokerto, I. (2020). Manajemen Program Pembiasaan Untuk Membentuk Karakter Mandiri Pada Anak di Paud Banyu Belik Purwokerto. Jurnal Thufula, 8(1). https://doi.org/10.21043/thufula.v8i1.7044 